\title{
DO VASOPRESSIN-RELATED PEPTIDES INDUCE HIPPOCAMPAL CORTICOSTERONE RECEPTORS? IMPLICATIONS FOR AGING ${ }^{1}$
}

\author{
ROBERT M. SAPOLSKY," LEWIS C. KREY, BRUCE S. MCEWEN, AND THOMAS C. RAINBOW* \\ Laboratory of Neuroendocrinology, The Rockefeller University, New York, New York 10021 and *Department of Pharmacology, \\ University of Pennsylvania Medical School, Philadelphia, Pennsylvania 19104
}

Received August 25, 1983; Revised December 14, 1983; Accepted December 14, 1983

\begin{abstract}
The aged rat shows a decline in hippocampal corticosterone receptors and dysfunction in learning and adrenocortical physiology previously linked to glucocorticoid effects upon the hippocampus. The Brattleboro rat, congenitally lacking vasopressin, also has a low number of hippocampal glucocorticoid receptors, as well as learning and endocrine impairments similar to those seen in the aged. Centrally acting vasopressin analogues correct the receptor loss in the hippocampus in the Brattleboro rat but do not influence the hippocampal receptor deficit in the aged rat. Quantitative and high resolution autoradiographic procedures were utilized to characterize the glucocorticoid receptor deficit in the aged and Brattleboro rats. Quantitative autoradiography showed that in both aged and Brattleboro subjects, losses in receptors were most extreme in the pyramidal layer of the CA3a region. High resolution autoradiography revealed striking differences in the cellular basis of the receptor losses. Brattleboro rats had decreased binding of $\left[{ }^{3} \mathrm{H}\right]$ corticosterone per neuron, whereas aged subjects, in addition, had significant losses in the number of corticosterone-concentrating neurons. Taken together, our findings indicate that the glucocorticoid receptor deficit in the Brattleboro rat probably represents a vasopressin-influenced defect in the synthesis or degradation of the receptor, whereas in the aged rat the deficit originates from loss of both receptor per neuron and the steroid-concentrating neurons themselves, and thus is most likely a permanent and pharmacologically insensitive deficit.
\end{abstract}

The aged rat displays a relatively selective decline in corticosterone receptor number in the hippocampus (Sapolsky et al., 1983a). In addition, it has deficits in a variety of forms of learning (Finch and Hayflick, 1977; Landfield et al., 1981) and a loss of sensitivity to glucocorticoid negative-feedhack regulation of its hypothalamic-pituitary-adrenal (HPA) axis (Riegle and Hess, 1972; Sapolsky et al., 1983b). Effects on both activeavoidance learning and negative-feedback regulation of the HPA axis are influenced by glucocorticoids and may occur, at least in part, through their effects upon the hippocampus (Van Hartesveldt, 1975; Bohus and DeKloet, 1979). Thus, the loss of hippocampal corticosterone receptors during aging may be responsible for some of these learning and endocrine deficits (Sapolsky et al., 1983a, b).

\footnotetext{
${ }^{1}$ We wish to thank Dr. Maurice Manning, Medical College of Ohio at Toledo, for the gift of the dGVP. This work was supported by a predoctoral grant from the National Institute of Aging to R. M. S.

2 To whom reprint requests should be sent.
}

The Brattleboro rat, a strain with a congenital absence of vasopressin synthesis, resembles the aged rat in several ways. Brattleboro rats lack vasopressin within the brain, and aged subjects show significant declines in vasopressin within the CNS (Dorsa and Bottemiller, 1982; Sokol and Valtin, 1982). Like the aged rat, the Brattleboro rat shows a selective depletion of hippocampal corticosterone receptors; furthermore, it shows disruptions in avoidance learning and is relatively insensitive to glucocorticoid's negative-feedback actions within the HPA axis (Bohus et al., 1975; Bailey and Weiss, 1981; Veldhuis and de Kloet, 1982; R. Sapolsky, submitted for publication).

In the Brattleboro rat, the hippocampal corticosterone receptor deficit appears to be due to the absence of a vasopressin-synthesizing neuronal projection from the paraventricular nucleus of the hypothalamus to the hippocampus (Buijs, 1978). Moreover, administration of vasopressin, or of centrally acting vasopressin analogues with no peripheral diuretic or ACTH-releasting effects, has been shown to correct the receptor deficit (Veldhuis and de Kloet, 1982). This treatment also improves many 
of the abnormalities in learning and negative-feedback insensitivities found in untreated Brattleboro subjects (de Wied et al., 1978; R. Sapolsky, unpublished results). Such findings raise the exciting possibility that vasopressin or centrally acting analogues might be "inducers" of hippocampal corticosterone receptors and, thus, correct the receptor deficit and its functional concomitants in elderly rats. We test this possibility in the present study.

\section{Materials and Methods}

Subjects for the aging studies were male Fischer 344 strain rats (Charles River Breeding Farms, Wilmington, $\mathrm{MA}$ ), either 3 to 5 months of age or 24 to 26 months of age. Subjects were cesarean delivered and housed in pathogen-free colonies. Remaining subjects were either homozygotic diabetes insipidus Brattleboro rats or LongEvans strain controls (male subjects, 5 months of age), obtained from Blue Spruce Farms, Altamont, NY). All rats were given access to food and water ad libitum and were maintained on a 14:10-hr light/dark cycle (lights on: 5:00 A.M. to 7:00 P.M.).

In experiments with vasopressin analogues, $2 \mu \mathrm{g}$ of des-glycinamide-arginine vasopressin (dGVP) were administered daily for 7 days. Peptides were dissolved in a slow-release zinc phosphate solution (de Wied, 1966). Control subjects were injected with the zinc phosphate solution alone. dGVP was generously supplied by Dr. Maurice Manning, Medical College of Ohio at Toledo.

For cytosolic corticosterone receptor assays, subjects were adrenalectomized $12 \mathrm{hr}$ before decapitation. A 12 $\mathrm{hr}$ interval, rather than the more frequent 24 -hr interval, was selected because of the poor postsurgical health status of both the elderly and Brattleboro rats. Following decapitation, the hippocampi (dorsal, ventral, and subiculum) from pairs of subjects were rapidly removed and homogenized in ice-cold $5 \mathrm{mM}$ Tris buffer ( $\mathrm{pH} \mathrm{7.4)}$ containing $1 \mathrm{mM}$ EDTA, $10 \mathrm{~mm}$ sodium molybdate, $10 \%$ glycerol, and $1 \mathrm{~mm}$ dithiothreitol. The homogenate was centrifuged at $1^{\circ} \mathrm{C}$ for $30 \mathrm{~min}$ at $105,000 \times \mathrm{g}$. Aliquots $(250 \mu \mathrm{l})$ of cytosol were added to previously evaporated $\left[{ }^{3} \mathrm{H}\right]$ dexamethasone solutions (a concentration range of 5 to $40 \mathrm{~nm}$ determined by direct counting of aliquots). Nonspecific binding was determined in parallel incubations which also contained a 500-fold molar excess of corticosterone. Macromolecular bound steroid was separated from free steroid by passage through Sephadex LH-20 columns (Veldhuis and de Kloet, 1982), and the eluate was counted in Liquiscint (National Diagnostics, Somerville, NJ) at an efficiency of $35 \%$. Cytosol protein concentrations were determined (Lowry et al., 1951), and the results were standardized as femtomoles of $\left[{ }^{3} \mathrm{H}\right]$ dexamethasone bound per milligram of cytosolic protein. $B_{\max }$ and $K_{\mathrm{d}}$ values were derived by Schatchard analysis (Scatchard, 1949).

Quantitative autoradiography of $\left[{ }^{3} \mathrm{H}\right]$ corticosterone binding in vivo by untreated aged, Brattleboro, and control rats was conducted according to methods previously described using tritium-sensitive sheet film (LKB Ultrofilm, LKB Instruments, Inc., Gaithersburg, MD) (Sapolsky et al., 1983c). Three subjects of each group were adrenalectomized, injected subcutaneously $10 \mathrm{hr}$ later with $500 \mu \mathrm{Ci}$ of $\left[1,2,6,7-{ }^{3} \mathrm{H}\right]$ corticosterone $(82.1 \mathrm{Ci} / \mathrm{mmol}$; Amersham Corp., Arlington Heights, IL), and then decapitated $2 \mathrm{hr}$ later. This dose of $\left[{ }^{3} \mathrm{H}\right]$ corticosterone saturates brain receptors during this time course (Sapolsky et al., 1983a). Nonspecific binding was assessed in one subject from each group which received concurrent injections of $5 \mathrm{mg}$ of unlabeled corticosterone with the labeled steroid. Frozen $32-\mu \mathrm{m}$ thick sections of brain were cut with a cryostat at $-15^{\circ} \mathrm{C}$ and thaw-mounted onto subbed glass slides. The slides were stored overnight at $-40^{\circ} \mathrm{C}$, dried on a hot plate, and then apposed against LKB Ultrofilm in cardboard x-ray film cassettes. After a 60-day exposure at room temperature, the film was developed in Kodak GB/X x-ray film developer, and the optical densities of the autoradiograms were quantified by projecting the autoradiogram onto a movable photocell connected to a digital voltmeter. The anatomical resolution of the densitometer readings corresponded to a region $50 \mu \mathrm{m}$ in diameter on the brain section. The brain sections were stained with cresyl violet for anatomical reference. The optical densities of the autoradiograms were converted into molar amounts of bound corticosterone with the use of tritium brain-mash standards (Unnerstall et al., 1982). Different hippocampal cellular subfields were distinguished according to the method of Lorente de No (1934).

High resolution steroid autoradiography was conducted according to the method of Gerlach and McEwen (1972). Aged, Brattleboro, and control subjects (threc per group) were adrenalectomized, injected subcutaneously $10 \mathrm{hr}$ later with $100 \mu \mathrm{Ci}$ of $\left[{ }^{3} \mathrm{H}\right]$ corticosterone, and decapitated $2 \mathrm{hr}$ later. Frozen, $6-\mu \mathrm{m}$ thick sections were cut with a cryostat at $-18^{\circ} \mathrm{C}$ and transferred with a fine brush onto emulsion-dipped slides. Slices were taken every $75 \mu \mathrm{m}$ through the hippocampus. Slides were desicated and stored in the dark at $4^{\circ} \mathrm{C}$ for 6 months before being developed. Slides were then stained with cresyl violet for anatomical reference.

The number of corticosterone-concentrating neurons and the number of grains concentrated per neuron were determined in each slice by microscopic examination. After orienting at the center of a particular cell field, the number of neurons within the field of vision was counted. The average size of neurons was assessed by dividing the number of reticle grids overlapped by cells by the number of cells; average background grain density in neuropil was then determined for an area equivalent to the average neuron size. With this information, we then determined the total number of neurons within view which concentrated grains at a rate higher than background. Twenty such cells were randomly chosen per cell field per slice, and the precise number of grains (above background) was counted.

All statistical analyses were determined with one-way analysis of variance followed by Newman-Keuls tests.

\section{Results}

The Brattleboro rat had a significant $(p<0.05)$ decrease of $25 \%$ in the number of cytosolic corticosterone receptors in the hippocampus; there was no change in receptor affinity (Table I). Furthermore, treatment of Brattleboro subjects for 1 week with dGVP normalized 
receptor number within the range of Iong-Fvans controls. However, treatment with dGVP had no effect on receptor number or affinity in Long-Evans control rats.

Aged rats had a significant $(p<0.01)$ decrease of $37 \%$ in the number of hippocampal corticosterone receptors. There was no change in affinity of the receptor (Table I). Treatment with dGVP failed to normalize this receptor deficit.

Because of this discrepancy in the effects of dGVP on the Brattleboro and aged rats, we used quantitative autoradiography to compare the hippocampal receptor loss between the two groups. In particular, we wanted to determine whether the similarities of receptor depletion apparent on the level of the whole hippocampus were localized to more neuroanatomically discrete regions. We utilized a method for quantitative autoradiography of steroid binding, using densitometry of tritium-sensitive film (Sapolsky et al., 1983c). Anatomical similarilies emerged in the analyses of the aged and Brattleboro brains (Fig. 1). In the subiculum, CA4 region, and dentate gyrus, corticosterone binding resembled that seen in the normal young controls. In the aged rat brains, significant decreases in binding were noted in the pyramidal layer of CA3a, while trends toward significant declines were

TABLE I

Effect of 1-week administration of des-glycinimide arginine vasopressin on [ ${ }^{3} H$ ]dexamethasone binding in the hippocampus

$B_{\max }$ (femtomoles per milligram of cytosolic protein) and dissociation constant (moles/liter $\times 10^{9}$ ) were derived by Scatchard analysis. Values are mean $\pm \mathrm{SE}$. Correlation coefficients $(r)$ were derived from linear regression analysis of reciprocal plots. $n$ represents the number of pairs of subjects in each experiment. * and ** indicate lower binding, relative to controls, at the 0.05 and 0.01 levels of significance, respectively (NewmanKeuls test following one-way analysis of variance).

\begin{tabular}{lcccc}
\hline \multicolumn{1}{c}{ Subject } & $B_{\max }$ & $K_{\mathbf{d}}$ & $r$ & Percentage of Control \\
\hline Control Long-Evans $(n=4)$ & $125 \pm 8$ & $1.3 \pm 0.2$ & 0.97 & 1.00 \\
Untreated Brattleboro $(n=4)$ & $95 \pm 12^{*}$ & $1.2 \pm 0.2$ & 0.88 & 0.76 \\
Treated Brattleboro $(n=4)$ & $120 \pm 6$ & $1.1 \pm 0.1$ & 0.93 & 0.96 \\
Treated Long-Evans $(n=4)$ & $113 \pm 9$ & $1.1 \pm 0.1$ & 0.91 & 0.90 \\
Young Fischers $(n=5)$ & $97 \pm 13$ & $2.0 \pm 0.5$ & 0.95 & 1.00 \\
Untreated old Fischers $(n=8)$ & $62 \pm 6^{* *}$ & $1.4 \pm 0.3$ & 0.89 & 0.63 \\
Treated old Fischers $(n=8)$ & $55 \pm 7^{* *}$ & $1.6 \pm 0.4$ & 0.96 & 0.56 \\
\hline
\end{tabular}

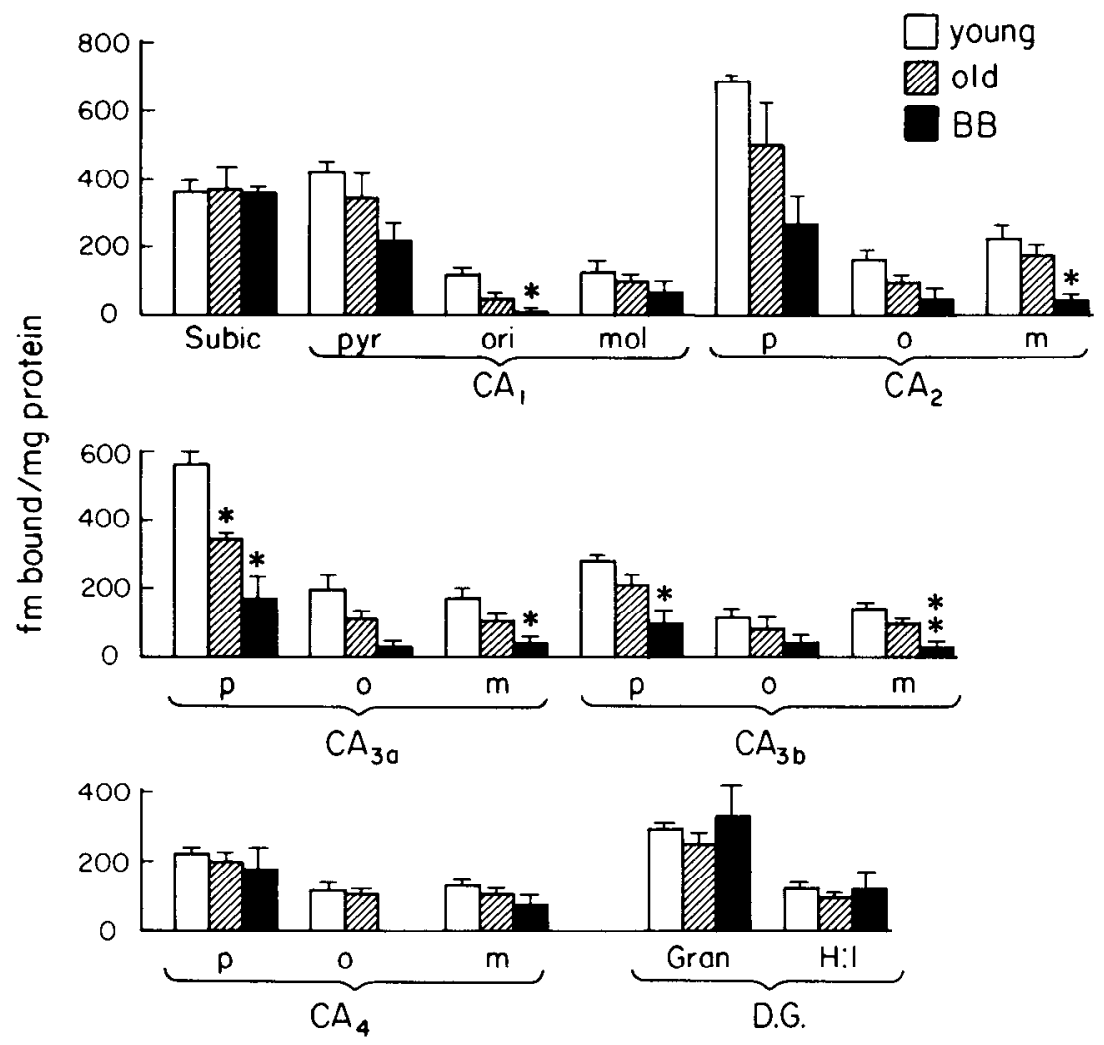

Figure 1. Femtomoles of $\left[{ }^{3} \mathrm{H}\right]$ corlicosterone bound per milligram of protein in various hippocampal regions in control, aged, and Brattleboro subjects, as analyzed by quantitative autoradiography ( $n=3$ for each group). Values are mean \pm S.E. $*$, a decrease in binding relative to controls, at the 0.05 level of significance (Newman-Keuls test following one-way analysis of variance). 
observed in CA1, CA2, and CA3b. In the Brattleboro rat, substantial losses in binding were also noted in the CA3a region, and there were also significant declines in the pyramidal layer of CA3b and scattered losses elsewhere. Thus, the two groups were similar in that the deficit in receptor binding was primarily restricted to CA3a. In the remainder of the hippocampus, what were nonsignificant trends toward losses in the aged were generally more extreme significant ones in the Brattleboro.

In order to understand further the neuroanatomical similarity of the receptor deficit in the aged and Brattleboro rat, we next examined the cellular basis of the binding declines in the hippocampi of the two groups by assessing $\left[{ }^{3} \mathrm{H}\right]$ corticosterone binding with high resolution steroid autoradiography. We sought to determine whether the binding losses in these groups were due to fewer receptors per neuron and/or to fewer receptorcontaining neurons. We analyzed the CA4 pyramidal layer, an area in which neither group showed a loss of binding.

Figures 2 to 4 illustrate the striking differences observed between the aged and Brattleboro rats. Among the cells of the CA2 and CA3a region which specifically concentrated $\left[{ }^{3} \mathrm{H}\right]$ corticosterone at a higher level than background, both the aged and Brattleboro rats showed fewer numbers of grains per pyramidal neuron than did controls (Figs. 2 and 4). In each case, approximately $50 \%$ fewer grains were observed in each neuron. There were no changes in grain number in the CA4 region. In addition to these losses in the intensity of binding of $\left[{ }^{3} \mathrm{H}\right]$ corticosterone, aged rats showed a significant decline in the number of steroid-concentrating neurons. However, no such loss was seen in the Brattleboro rats (Figs. 3 and 4). In CA2 and CA3a, all three groups had equivalent numbers of unlabeled neurons. Aged subjects, however, showed considerable declines in the numbers of labeled neurons and the percentage of total neurons which specifically concentrated corticosterone. Again, no changes

Number of Grains / Corticosterone-Concentrating Neuron

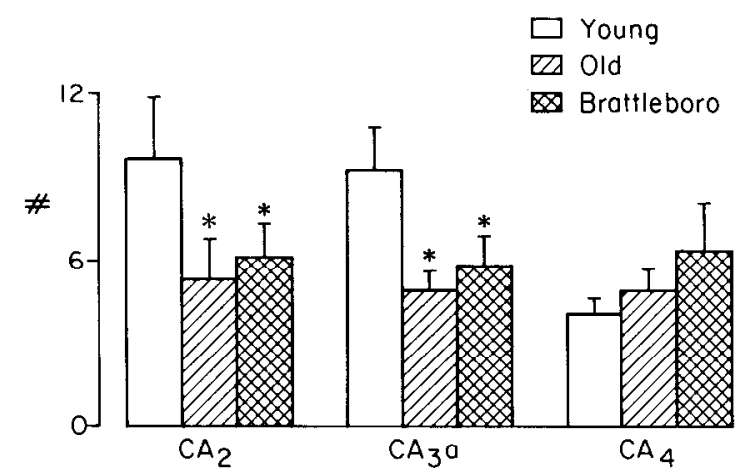

Figure 2. Number of silver grains overlying pyramidal neurons of the CA2, CA3a, and CA1 regions in control, aged, and Brattleboro rats. Twenty cells which concentrated grains at levels higher than background were chosen per cell field per slide in each subject, and then number of grains (above background) was counted ( $n=3$ subjects for each group). Values are mean \pm S.E. *, decreased numbers of grains relative to controls at the 0.05 level of significance (Newman-Keuls test following one-way analysis of variance).

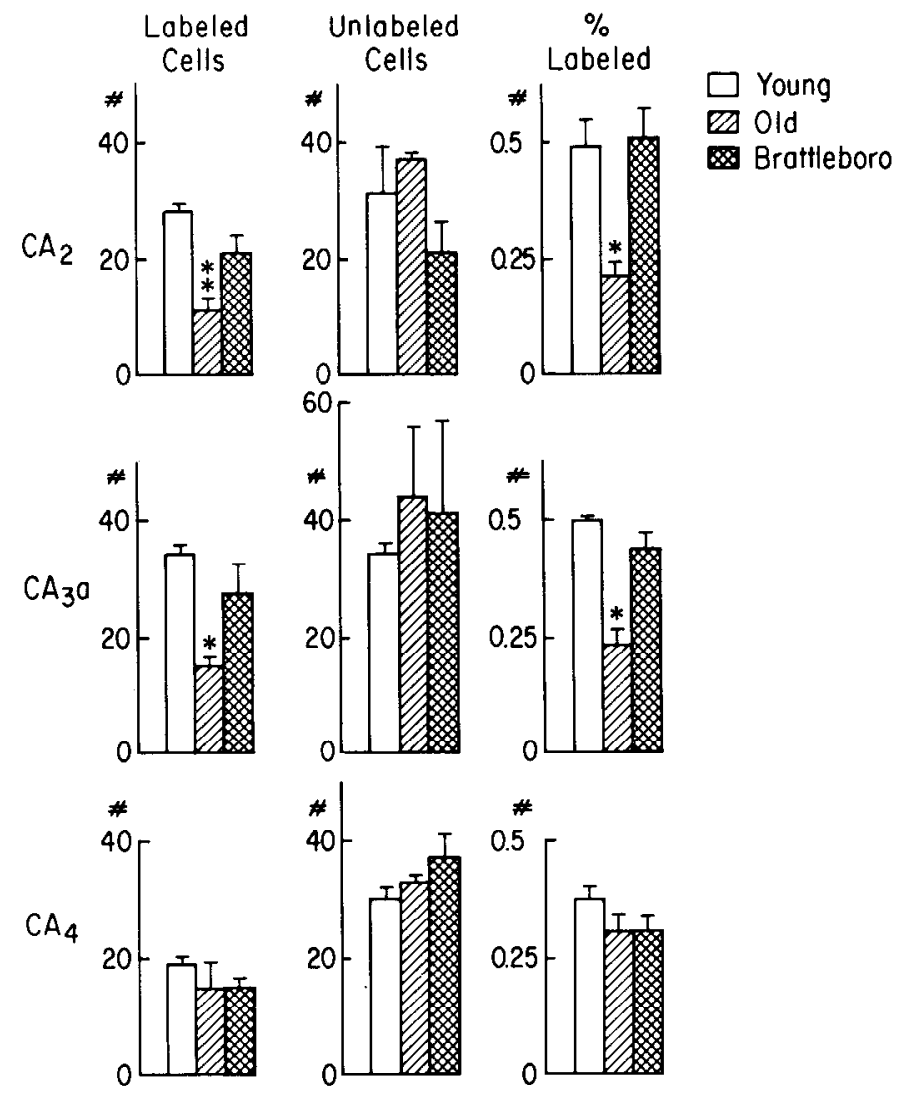

Figure 3. Analysis of the number of $\left[{ }^{3} \mathrm{H}\right]$ corticosteroneconcentrating neurons in pyramidal regions of CA2, CA3a, and CA4 in control, aged, and Brattleboro rats. Within each cell field, the number of neurons, average neuron size, and average background grain density in neuropil in an area equivalent to the size of an average neuron were determined. With this information, the number of neurons specifically concentrating $\left[{ }^{3} \mathrm{H}\right]$ corticosterone was determined, as were the number of unlabeled neurons and the percentage of neurons which were labeled. * and $* *$, significantly fewer cells, relative to controls, at the 0.05 and 0.01 levels of significance, respectively (Newman-Keuls test following one-way analysis of variance).

in either group were seen in CA4. Taken together, these autoradiographic data indicate that the loss of corticosterone binding in $\mathrm{CA} 2$ and $\mathrm{CA} 3 \mathrm{a}$ in the aged rat is associated with a loss of corticosterone-concentrating neurons and a loss of receptors per neuron. The receptor deficit in Brattleboro rats appears to be associated with a loss of receptors per neurons.

\section{Discussion}

The senescent male rat and the Brattleboro rat share a number of physiological and behavioral dysfunctions. Both have extensive and relatively selective losses of cytosolic corticosterone receptors in their hippocampus, and both have possibly resultant deficits in some aspects of learning and negative-feedback regulation of corticosterone secretion (see the introduction). Furthermore, both have partial or complete depletions of vasopressin throughout the brain. The demonstration that administration of vasopressin or vasopressin analogues to the Brattleboro rat corrected both the corticosterone receptor deficit (this study) and the concomitant cognitive 

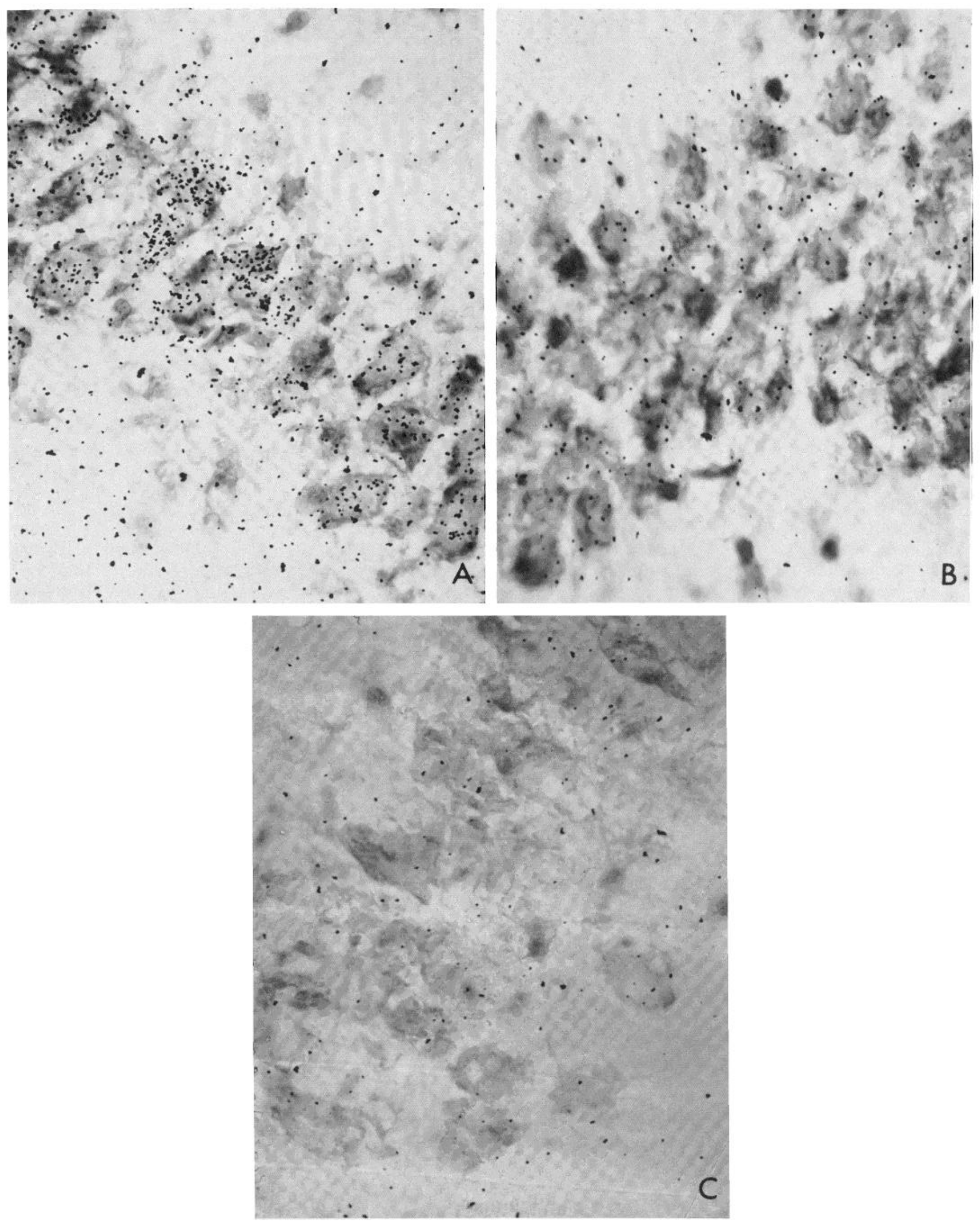

Figure 4. Photomicrographs of CA3a pyramidal cell region of hippocampus in $(A)$ a control subject, $(B)$ an aged Fischer rat, and $(C)$ a Brattleboro rat. Magnification $\times 400$. 
and neuroendocrine disorders (see the introduction) suggested that such treatment might be therapeutic in the aged rat. This was not the case, and the remainder of this study examined the differences in the syndromes of receptor loss in the aged and Brattleboro hippocampus which inight explain the differing reversibility of the deficit. We find that, despite the similarity of the neuroanatomical localization of the hippocampal receptor loss in the two groups, they differ markedly in the cellular basis of the loss. In the case of the Brattleboro rat, the reduction in binding is attributable to decreased corticosterone binding per neuron, whereas the aged, in addition, show a loss of neurons which bind corticosterone.

The hippocampal receptor losses observed agree with previous reports concerning Brattleboro (Veldhuis and de Kloet, 1982) and aged rats (Sapolsky et al., 1983a). In neither case is there a change in receptor affinity. In aged rats, receptor loss is specific to the neuronal, rather than glial, pool and there is no impairment in translocation of the steroid-receptor complex from the cytosol to cell nucleus (Sapolsky et al., 1983a). In agreement with previous reports (Veldhuis and de Kloet, 1982), the Brattleboro receptor loss is correctable after a week of treatment with the vasopressin analogue, dGVP. The efficacy of this analogue, which has no peripheral diuretic effects or ACTH-releasing effects upon the pituitary (Veldhuis and de Kloet, 1982), suggests that it acts directly on the hippocampus, substituting for the vasopressin-containing projection to the hippocampus that is congenitally absent in these subjects. We have subsequently found that receptor concentrations decline to pretreatment levels within 6 weeks after the end of dGVP treatment (unpublished observation). Thus, the modulation of the hippocampal corticosterone receptor pool in the Brattleboro rat by dGVP is rapid and readily reversible. In contrast, such treatment failed to normalize the similar receptor deficit in the aged hippocampus or to elevate receptor concentrations in the normal hippocampus.

Because of this discrepancy in sensitivity to dGVP treatment, we next examined the aged and Brattleboro hippocampi with tritium-sensitive LKB film autoradiography (Sapolsky et al., 1983c), to determine whether the receptor loss is anatomically equivalent in the two groups when examined in detail. The two groups were quitc similar in the binding pattern throughout the hippocampus. In both groups, the most severe losses occurred in the CA3a region, whereas no decreases occurred in the dentate, subiculum, or CA4 region. Throughout the remainder of the hippocampus, the aged generally showed nonsignificant trends toward declines, whereas Brattleboro subjects showed larger ones. Thus, the anatomical distribution of the receptor loss was similar in both groups and provides no clue toward explaining the ready reversibility of the Brattleboro deficit and the intractability of the aged one. Current limited understanding of the physiology and anatomy of the hippocampus precludes speculation about possible mechanisms relating the receptor losses with the observed learning and endocrine abnormalities in these animals.

Because the quantitative autoradiographic analysis did not answer questions concerning the differing reversibility of the receptor deficits in the two groups, we next examined the deficits with high resolution steroid autoradiography, determining whether losses were due to decreased binding per neuron and/or to decreased numbers of neurons which bound corticosterone. Our analyses showed that the Brattleboro rat has a normal number of corticosterone-concentrating neurons in an area such as the pyramidal layer of CA3a, but it binds less of the hormone per cell. In contrast, the aged rat loses a significant percentage of its corticosterone-concentrating neurons, and the surviving ones all bind less of the hormone than did the average cell in young control rats. Alterations of numbers of receptors per neuron, as seen in the Brattleboro, most likely represent rather rapid and reversible biochemical changes, such as rate of synthesis or degradation of receptors. These may be regulated by the neuronal inputs reaching the cells (Nock and Feder, 1982). Similar mechanisms have also been invoked to explain the rapid and reversible alterations in size of receptor pools following up- or down-regulation (McEwen et al., 1974; Cidlowski and Cidlowski, 1981; Sapolsky et al., 1984). However, the loss of corticosterone-containing neurons in the aged appears to represent an inherently more gradual and seemingly less reversible process.

Pharmacologic treatment with glucocorticoids destroys hippocampal neurons (Muhlen and Ockenfels, 1969). Moreover, the work of Landfield and colleagues $(1978,1981)$ has shown that the age-related loss of hippocampal pyramidal neurons is a correlate of increasing glucocorticoid titers in the aged rat, and adrenalectomy at middle age will reverse this decline. If glucocorticoids cause the loss of hippocampal neurons during aging, as Landfield's results indicate, it is likely that they would be most destructive to neurons containing the highest concentration of corticosterone receptors. This would explain both the general loss of corticosterone-concentrating neurons during aging and the low numbers of grains bound in neurons remaining, as glucocorticoids over the lifespan would be most destructive to those neurons which bound the hormone avidly.

In conclusion, we have observed a quantitatively and anatomically similar loss of corticosterone receptors in the hippocampus of the aged and Brattleboro rat. This receptor loss may underlie the glucocorticoid-influenced behavioral and endocrine abnormalities that the two groups share. However, the receptor deficits in the aged and Brattleboro rats are the sequelae of markedly different cellular mechanisms of receptor loss. In the case of the Brattleboro rat, the full complement of corticosterone-concentrating neurons appears to be intact, but some biochemical aspects of receptor regulation, presumably those under the partial influence of vasopressin, are compromised. In contrast, corticosterone-concentrating neurons in the aged rat are irreversibly lost, perhaps as a result of cumulative glucocorticoid exposure. This loss of cells, rather than receptors per cell, suggest that the deficit in the aged subject represents a pharmacologically intractable lesion.

\section{References}

Bailey, W., and J. Weiss (1981) Avoidance conditioning and endocrine function in Brattleboro rats. In Endogenous Peptides and Learning and Memory Processes, J. Martinez, B. 
Jensen, B. Messing, H. Rigter, and J. McGaugh, eds, pp. 371-395, Academic Press, Inc., New York.

Bohus, B., and E. de Kloet (1979) Behavioral effects of neuropeptides related to LPH and ACTH (endorphins, enkephalins, ACTH fragments) and corticosteroids. In Interaction within the Brain-Pituitary-Adrenocortical System, M. Jones, B. Gilham, M. Dallman, and S. Chattopathyay, eds., pp. 752, Academic Press, Inc., New York.

Bohus, B., T. van Wimersma-Greidanus, and D. de Wied (1975) Behavioral and endocrine responses of rats with hereditary diabetes insipidus (Brattleboro strain). Physiol. Behav, 14: 609-615.

Buijs, R. (1978) Intra- and extrahypothalamic vasopressin and oxytocin pathways in the rat. Cell Tissue Res. 192: 423.

Cidlowski, J., and N. Cidlowski (1981) Regulation of glucocorticoid receptors by glucocorticoids in cultured HeLa S3 cells. Endocrinology 109: 1975-1982.

de Wied, D. (1966) Inhibitory effect of ACTH and related peptides on extinction of conditioned avoidance behavior in rats. Proc. Soc. Exp. Biol. Med. 122: 28-35.

de Wied, D., B. Bohus, J. van Ree, I. Urban, and T. van Wimersma-Greidanus (1978) Neurohypophyseal hormones and behavior. In Neurohypophysis, A. Moses and L. Shore, eds., pp. 201-223, S. Karger AG, Basel.

Dorsa, D., and L. Bottemiller (1982) Age-related changes of vasopressin content of microdissected areas of the rat brain. Brain Res. 242: 151-156.

Finch, C., and L. Hayflick (1977) Handbook of the Biology of Aging, Van Nostrand Reinhold Co., Florence, KY.

Gerlach, J., and B. McEwen (1972) Rat brain binds adrenal steroid hormone: Radioautography of hippocampus with corticosterone. Science 175: 1133-1136.

Landfield, P., J. Waymire, and G. Lynch (1978) Hippocampal aging and adrenocorticoids: Quantitative correlation. Science 202: 1098-1102.

Landfield, P., R. Baskin, and T. Pitler (1981) Brain aging correlates: Retardation by hormonal-pharmacological treatments. Science 214: $581-584$.

Lorente de No, R. (1934) Studies on the structure of the cerebral cortex. II. Continuation of the study of the ammonic system. J. Psychol. Neurol. 46: 113-177.

Lowry, O. H., N. J. Rosebrough, A. L. Farr, and R. J. Randall (1951) Protein measurement with the Folin phenol reagent.
J. Biol, Chem, 193: 265-275.

McEwen, B., G. Wallach, and C. Magnus (1974) Corticosterone binding to hippocampus: Immediate and delayed influences of the absence of adrenal secretion. Brain Res. 70; 321-337.

Muhlen, K., and H. Ockenfels (1969) Morphologische Veranderungen im Diencephalon und Telecephalon nach Storungen des Regelkreises Adenohypophyse-Nebennierenrinde. III. Ergebnisse bein Meerschweinchen nach Verabreichung von Cortison und Hydrocortison. Z. Zellforsch. 93: 126-141.

Nock, B., and H. Feder (1982) Neurotransmitter modulation of steroid action in target cells that mediate reproduction and reproductive behavior. Neurosci. Biobehav. Rev. 5: 437-447.

Riegle, G., and G. Hess (1972) Chronic and acute dexamethasone suppression of stress activation of adrenal cortex in young and aged rats. Neuroendocrinology 9: 175-187.

Sapolsky, R., L. Krey, and B. S. McEwen (1983a) Corticosterone receptors decline in a site-specific manner in the aged rat brain. Brain Res. 289: 235-240.

Sapolsky, R., L. Krey, and B. McEwen (1983b) The adrenocortical stress-response in the aged male rat: Impairment of recovery from stress. Exp. Geront. 18: 55-64.

Sapolsky, R., B. McEwen, and T. Rainbow (1983c) Quantitative autoradiography of $3 \mathrm{H}$ corticosterone receptors in rat brain. Brain Res. 271: 331-337.

Sapolsky, R., L. Krey, and B. McEwen (1984) Stress downregulates corticosterone receptors in a site-specific manner in the brain. Endocrinology 114: 287-292.

Scatchard, G. (1949) The attractions of proteins for smaller molecules and ions. Ann. N. Y. Acad. Sci. 51: 660-703.

Sokol, H., and H. Valtin (1982) The Brattleboro rat. Ann. N. Y. Acad. Sci. 394: 828.

Unnerstall, J., D. Niehoff, M. Kuhar, and J. Palacios (1982) Quantitative receptor autoradiography using $3 \mathrm{H}$-Ultrofilm: Application to multiple benzodiazepine receptors. J. Neurosci. Methods 6: 59-78.

Van Hartesveldt, C. (1975) The hippocampus and regulation of the hypothalamic-hypophyseal-adrenal cortical axis. In 'I'he hippocampus, R. Isaacson and K. Pribram, eds., Vol. 1, pp. 375-392, Plenum Press, New York.

Veldhuis, H., and E. de Kloet (1982) Vasopressin-related peptides increase the hippocampal corticosterone receptor capacity of diabetes insipidus (Brattleboro) rats. Endocrinology 110: $153-157$. 